\title{
A REVIEW OF OUR GEOMETRID CLASSIFICATION.-No. 3.
}

RICHARD F. PEARSALL, BROOKLYN, N. Y.

The endeavour to place our species under genera based upon structural characters, easily observed, yet possessing stability, has resolved itself into an extensive study and rearrangement of the species themselves, especially of the type forms, which in a number of cases are found to differ from the generic requirements. I need not rehearse here the opinions set forth by Mr. Meyrick, Dr. Hulst and others as to the propriety of using certain characters, whether sexual or not, in defining genera. I have simply, through my own investigations, sought to determine upon the value of those which in our fauna I have tested and found to be reliaple, and these I intend to use in future descriptive work, dividing them into basic and auxiliary groups

\section{Basic Group.}

In this group the characters do not vary as between individuals, except in rarely aberrant forms, which will be noted.

The antennce. They may be filiform, flattened $(\boldsymbol{D})$, compressed $(\widehat{V})$, unipectinate, bipectinate, serrate, lamellate, or dentate, and smocth, ciliate, fasciculate, or spinose. They generaily differ between sexes of the same species.

The palpi vary in length of joints often between sexes of the same species, but not between individuals of the same sex. Their position is not given, since it is not always natural after death. The comparative terms used to describe them may be thus limited as nearly as is possible :

Short, when looking downward vertically their tips are not, or are just visible beyond the front.

Moderate, when they project beyond the front equal to the width of it between the orbits.

Long, when they exceed that limit.

The frontal tubercles and tufts.

The tongue.

The claws on fore tibice.

$V$ ins 5 and 8 of hind wings, the former by its presence or absence, the latter by its conneciion with or separation from the discal cell, are important divisors of families, as well as genera.

March, 1907. 


\section{The frenulum.}

\section{The tibial spurs.}

The hair pencil on hind tibiæ of male. Dr. Hulst used this as a reliable factor, and my experience fully warrants the value he placed upon it.

\section{Auxiliary Group.}

The characters here classed are not to be wholly relied upon. Many of them will be used as useful aids, but will be omitted where found too unstable.

The tufts of thorax, abdomen, and patagia, chiefly because of their liability to removal by abrasion. The same might seem applicable to the hair pencil, but in only one genus (Epimecis) have I had any difficulty with it.

Venation (except veins 5 and 8 of hind wings).

The foveal gland beneath wings. In some Ennominæ it is well developed, in others difficult of detection, or absent, and thus falls without the pale of fixed characters, but is useful in defining certain genera.

The accessory cell. The extensive use which has been made of the accessory cell by Dr. Hulst in the separation of Geometrid genera, following the assertion of Mr. Meyrick that it was an invariable structure, seems not to be warranted, at least so far as the American fauna is concerned. Selecting species in which I have considerable material, I give the result of an investigation, which it was not necessary to extend because here is enough evidence to effectually debar its future use. Of Cladara atroliturata, Walk., which, according to Hulst, should have two acc'y cells, out of 58 examples tested, 56 were normal and two had only one cell. Of Nyctobia limitaria, Walk., i $5^{8}$ examples divided as follows: 28 had one cell, 2 I had one cell in one wing and two in the other, while 109 were normal. Of Tephroclystia latipennis, Hulst, with one acc'y cell, 16 examples separated thus: 9 with one cell, 7 with two cells. Here the anomaly is shown, viz: 9 specimens with one cell would go into the genus Tephroclystia, while the other 7 of the same species would fall into Eucymatoge, an impossible situation, hence I have abandoned its use almost entirely, and by so doing it becomes imperative that there be a rearrangernent of the genera and species of Hydriomeninæ.

(To be continued.) 


\section{$2 \mathrm{BHL}$ Biodiversity Heritage Library}

1907. "A review of our geometrid classification. No. 3." The Canadian entomologist 39, 91-92. https://doi.org/10.4039/Ent3991-3.

View This Item Online: https://www.biodiversitylibrary.org/item/22084

DOI: https://doi.org/10.4039/Ent3991-3

Permalink: $\underline{\text { https://www.biodiversitylibrary.org/partpdf/8228 }}$

\section{Holding Institution}

MBLWHOI Library

\section{Sponsored by}

MBLWHOI Library

\section{Copyright \& Reuse}

Copyright Status: NOT_IN_COPYRIGHT

This document was created from content at the Biodiversity Heritage Library, the world's largest open access digital library for biodiversity literature and archives. Visit BHL at https://www.biodiversitylibrary.org. 